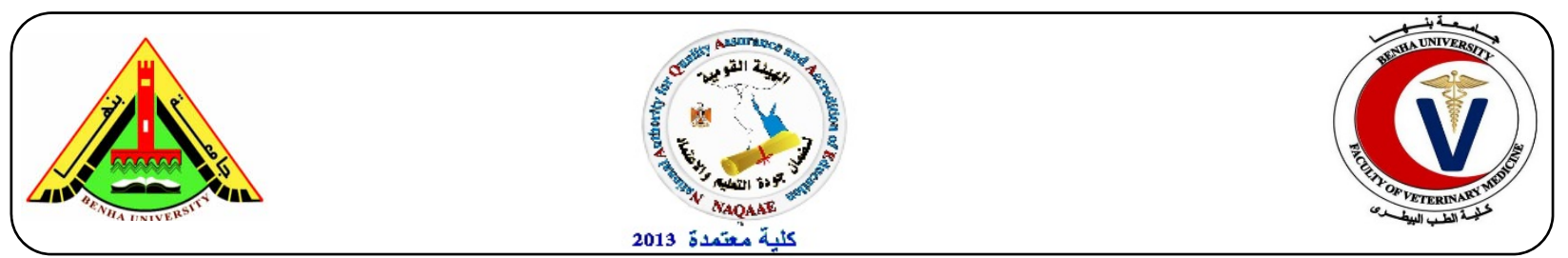

\title{
Detection of virulence genes of enterohaemorrhagic $E$. Coli isolated from some meat products by polymerase chain reaction.
}

\author{
Ashraf A. Abd El Tawab ${ }^{1}$, Fatma I. El-Hofy ${ }^{1}$, Shaimaa M. Nada ${ }^{2}$, Rasha A. A. Deiab ${ }^{2}$ \\ ${ }^{1}$ Department of Bacteriology, Immunology and Mycology, Faculty of Veterinary Medicine, Benha \\ University. ${ }^{2}$ Animal Health Research "Shebin El- Kom branch".
}

\section{A B S T R A C T}

A grand total of 105 meat product samples of minced meat, sausage and luncheon (35 of each) were duplicated bacteriologically examined to detect Enterohaemorrhagic E.coli prevalence and some virulence genes. One replicate was processed for $E H E C$ non $\mathrm{O}_{157}$ by using conventional method for isolation and identification of E.coli and the other for E.coli $\mathrm{O}_{157}: \mathrm{H}_{7}$, then serological typing and PCR technique for specific stx 1 , stx2, cvcC and hlyA genes from 6 random samples were applied. E.coli was isolated from 12 samples (34\%), 9 samples (25.7\%) and 11 samples (31\%) of the examined minced meat, sausage and luncheon, respectively. The isolated serotypes of EHEC were $\mathrm{O}_{26}$ (5 strains) $15.6 \%, \mathrm{O}_{111}$ (3 strains) $9.4 \%$ and $\mathrm{O} 157$ (3 strains) 17.6\%. The incidence of EHEC $\mathrm{O}_{26}$ were (2 strains) 5.7\%, (2 strains) 5.7\%, (1 strain) $2.85 \%$, incidence of $\mathrm{O}_{157}: \mathrm{H}_{7}$ were (2 strain) $5.7 \%$, (1 strain) $2.85 \%, 0 \%$ in minced meat, sausage and luncheon, respectively. The incidence of $\mathrm{O}_{111}$ was $2.85 \%$ from each the type meat products. PCR results indicated that $s x_{2}$ and $c v a C$ virulence genes were detected in the same studied strain $(\mathrm{O} 157: \mathrm{H} 7$ from minced meat sample), while $s t x_{1}$ and hIyA genes were not detected. Accordingly, meat products may constitute an important reservoir for $E H E C$ and PCR technique is the most sensitive and efficient approach for detection of EHEC genes.

Keywords: Enterohaemorrhagic E.coli, Shigatoxins, PCR.

(http://www.bvmj.bu.edu.eg)

(BVMJ-29(1): 45-52, 2015)

\section{INTRODUCTION}

$E$ coli is commonly non virulent but some strains have adapted pathogenic or toxigenic virulence factors that make them virulent for man and animals (Malik and Memona, 2010). Pathogenic E.coli strains are serotyped on the basis of their $\mathrm{O}$ (somatic), $\mathrm{H}$ (flagellar), and $\mathrm{K}$ (capsular) surface antigen profiles into six categories: Enteroaggregative (EAEC), $(E H E C) / S h i g a$ toxin-producing E.coli (STEC), Enteroinvasive (EIEC), Enteropathogenic (EPEC), Enterotoxigenic (ETEC), and diffuse adherent (DAEC) (Nataro and Kaper, 1998 and Parry and Sharon, 2002). EHEC is defined as a subgroup of VTEC/STEC associated with human diseases which in addition to the verocytotoxin/shigatoxin producing capacity harbors additional genes that are important in virulence. Verocytotoxin producing E.coli (VTEC) is a term used to describe strains of E.coli characterized by the ability to produce verocytotoxin(s) (VT), or just verotoxins that are capable of killing Vero cells, a tissue culture line of monkey kidney cells. In addition to E.coli $O_{157}$, EHEC includes over 100 serotypes causing food borne illness, such as $\mathrm{O}_{26}, \mathrm{O}_{111}, \mathrm{O}_{113}$ and $\mathrm{O}_{121}$ (FAO and WHO, 2011). Detection of E. coli $\mathrm{O}_{157}: \mathrm{H}_{7}$ is based on phenotypic differences from most other serotypes: its inability to ferment sorbitol on MacConkey sorbitol agar and 
absence of b-glucuronidase activity in most strains (Adams and Moss, 2008). Shiga toxins (stxs) are considered to be the major virulence factor of VTEC and comprise a family of structurally related cytotoxins with similar biological activity. The two main groups consist of $s t x 1$, which is nearly identical to the toxin of $S$. dysenteriae type 1 , and stx2, which shares less than $60 \%$ amino acid sequence with $s t x_{l}$ (Chelsa and O'Brien, 1998). Colicins are antimicrobial proteins produced by one strains of E.coli to suppress the growth of other relative strains of E.coli (DiezGonzalez, 2007). PCR is a powerful molecular biology technique that was introduced to facilitate the detection of the E.coli virulence factors by using DNA probes that detect specific virulence factors (Nataro and Kaper, 1998).

\section{MATERIAL AND METHODS}

\subsection{Samples collection}

A grand total of 105 samples (35 each of minced meat, sausage and luncheon) were collected from small scale shopes with different sanitation levels at El-Menofiya governorate and transferred in an ice box directly to laboratory with a minimum delay to be bacteriologically examined.

\subsection{Samples collection}

Samples were analyzed by duplicate. One replicate was processed for EHEC

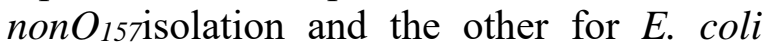
$\mathrm{O}_{157}: \mathrm{H}_{7}$ screening.

\subsubsection{Isolation and identification of E. coli}

The technique recommended by APHA (1992) by using MacConkey broth for enrichment then subculture on MacConkey agar and Eosin Methyline Blue (EMB) agar media. Suspected colonies (dark colonies with metallic sheen) for E.coli were picked up and sub cultured for purification.

\subsubsection{Isolation and Identification of Enterohaemorrhgic E.coli O157: H7}

A $25 \mathrm{~g}$ of each meat product were blended with $225 \mathrm{ml}$ of (mTSB) modified tryptic soya broth supplemented by Novobiocin $(20 \mathrm{mg} / \mathrm{l})$. Subculture was done on Sorbitol MacConkey Agar (SMAC) with Cefixime and Tellurite. All plates were incubated for 24-48 hours at $37^{\circ} \mathrm{C}$. Non sorbitol fermenting colonies (N.S.F), transparent colonies were picked up and sub cultured for purification.

\subsubsection{Identification of suspected E.coli isolates}

The purified colonies were morphologically identified by Gram stain and biochemical tests (Quinn et al., 2002).

\subsection{Antibacterial sensitivity test}

All the suspected isolates were serologically identified by slide agglutination according to Kok et al., (1996) by using rapid diagnostic E.coli antisera sets (DENKA SEIKEN Co., Japan) .while Non-sorbitol fermenting (NSF) isolates used monvalent $\mathrm{O}_{157}$ and $\mathrm{H}_{7}$ antisera.

\subsection{Antibacterial sensitivity test}

Primers used for detection of four virulence genes that may play a role in virulence of EHEC (Table 1).

Table (1): Primer sequences for virulence genes amplification of EHEC

\begin{tabular}{|c|c|c|c|}
\hline $\begin{array}{l}\text { Targe } \\
\mathrm{t} \\
\text { gene }\end{array}$ & $\begin{array}{l}\text { Primers sequences } \\
\left(5^{\prime}-3 \text { ') }\right.\end{array}$ & $\begin{array}{l}\text { product } \\
\text { (bp) }\end{array}$ & Reference \\
\hline st $x_{1}$ & $\begin{array}{l}\text { ACACTGGATGATCTCAGTGG } \\
\text { CTGAATCCCCCTCCATTATG }\end{array}$ & 614 & $\begin{array}{l}\text { Dipineto } \\
\text { et al., }\end{array}$ \\
\hline$s t x_{2}$ & $\begin{array}{l}\text { CCATGACAACGGACAGCAGTT } \\
\text { CCTGTCAACTGAGCAGCACTTT } \\
\text { G }\end{array}$ & 779 & $\begin{array}{l}2006 \\
\text { Dipineto } \\
\text { et al., }\end{array}$ \\
\hline Hly A & $\begin{array}{l}\text { ACGATGTGGTTTATTCTGGA } \\
\text { CTTCACGTGACCATACATAT }\end{array}$ & 165 & $\begin{array}{l}2006 \\
\text { Dipineto } \\
\text { et al., } \\
2006\end{array}$ \\
\hline cva C & $\begin{array}{l}\text { CACACACAAACGGGAGCTGTT } \\
\text { CTTCCCGCAGCATAGTTCCAT }\end{array}$ & 760 & $\begin{array}{l}\text { Yaguchi } \\
\text { et al., } \\
2007\end{array}$ \\
\hline
\end{tabular}


These genes were shiga toxins (stx $1, s t \times 2)$, haemolysin (hlyA) and colicine $\mathrm{V}$ production col $\mathrm{V}$ gene (cva $C$ ). PCR technique was applied on six random isolates $\left(\mathrm{O}_{26}\right.$ from minced meat sample and luncheon sample; $\mathrm{O}_{111}$ from luncheon and sausage sample; O157 from minced meat and sausage, two isolates for each) following QIAamp ${ }^{\circledR}$ DNA Mini Kit instructions (Catalogue no.51304): Emerald Amp GT PCR Master mix (Takara) Code No. RR310A and agarose gel electrophoresis (Sambrook et al., 1989).

\section{RESULTS}

Table (2): Prevalence of E.coli and N.S.F E.coli isolated from the examined meat product samples $(\mathrm{n}=35)$

\begin{tabular}{lcccc}
\hline $\begin{array}{l}\text { Type of } \\
\text { examined meat } \\
\text { products }\end{array}$ & \multicolumn{2}{c}{$\begin{array}{c}\text { Positive } \\
\text { samples of } \\
\text { E.coli }\end{array}$} & \multicolumn{2}{c}{$\begin{array}{c}\text { Positive samples } \\
\text { of N.S.F. E.coli }\end{array}$} \\
& No. & $\%$ & No. & $\%$ \\
\hline Minced Meat & 12 & 34 & 7 & 20 \\
Sausage & 9 & 25.7 & 6 & 17 \\
Luncheon & 11 & 31 & 4 & 11.4 \\
\hline Total & 32 & 30.5 & 17 & 16 \\
\hline \% were calculated according to the type of examined meat product \\
sample
\end{tabular}

Table (3): Serotypes of EHEC-non $\mathrm{O}_{157}$ and N.S.F. E.coli isolates

\begin{tabular}{cccccc}
\hline & \multicolumn{2}{c}{$\begin{array}{c}\text { Serotypes of EHEC } \\
\text { non O157 }\end{array}$} & & \multicolumn{2}{c}{$\begin{array}{c}\text { Serotypes of N.S.F } \\
\text { E. coli }\end{array}$} \\
\hline Isolates & $\begin{array}{c}\text { EHEC } \\
\text { Serogroup }\end{array}$ & O111:H4 & negati & O157 & negative \\
ve & & & \\
\hline $\begin{array}{c}\text { isolates } \\
\%\end{array}$ & 5 & 3 & 24 & 3 & 14 \\
& 15.6 & 9.4 & 75 & 17.6 & 82.4 \\
\hline
\end{tabular}

Table (4): Prevalence of EHEC serogroupes among the examined meat products $(n=35)$

\begin{tabular}{lccc}
\hline \multicolumn{1}{c}{ Tested } & EHEC & EHEC & EHEC \\
Sample & $\mathrm{O}_{26}$ & $\mathrm{O}_{111}$ & $\mathrm{O}_{157}$ \\
& No. $(\%)$ & No. $(\%)$ & No. (\%) \\
\hline Minced meat & $2(5.7)$ & $1(2.85)$ & $2(5.7)$ \\
Sausage & $2(5.7)$ & $1(2.85)$ & $12.85)$ \\
Luncheon & $1(2.85)$ & $1(2.85)$ & $0(0)$ \\
Total & $5(4.7)$ & $3(2.85)$ & $3(2.85)$ \\
\hline
\end{tabular}

$\%$ were calculated according to the type of examined meat product sample

Concerning the conventional methods for identification and isolation of E.coli isolates from meat samples, E.coli appeared as pink colonies on MacConkey agar, gave characteristic green sheen colonies on EMB., While N.S.F. E.coli were transparent on SMAC. E.coli strains were seen as Gramnegative, rods, arranged singly, pairs and groups, non-spore forming. Different biochemical reactions were done for confirmation of all suspected colonies: positive methyl red reaction and produced indole. They did not cause break down of urea and didn't grown in citrate medium. Reactions in TSI agar slant revealed yellow slant and butt with gas but no production of hydrogen sulphide gas was observed ,Meanwhile The results showed that E.coli was recovered in 32 samples with an incidence rate $30.5 \%$ represented; 34\%, 25.7\%, 31\%, while N.S.F.E.coli was isolated with percent $16 \%$ represented ; 20\%,17\%.11.4\% from minced meat, sausage and luncheon, respectively, table (2), Data in table (3) revealed that the serologically identified $32 \mathrm{E}$. coli isolates for EHEC nonO157 were 8 $(25 \%)$ isolates gave positive results with polyvalent antisera (2) more over 24 (75\%) isolates were negative by using the monvalent antisera The most commonly detected serogroups $\left(\mathrm{O}_{26}\right.$ and $\left.\mathrm{O}_{111}\right)$ represented as 5 strains were serotyping $\mathrm{O}_{26}(15.6 \%) ; 3$ strains $\mathrm{O}_{111}(9.4 \%)$, while typing of 17 N.S.F E. coli isolates were $3(17.6 \%)$ isolates can be identified serologically as $\mathrm{O} 157: \mathrm{H} 7$. while $14(82.4 \%)$ were negative.

Table (5): Prevalence of EHEC among the examined meat products samples $(n=35)$

\begin{tabular}{lcc}
\hline $\begin{array}{r}\text { Type of } \\
\text { products }\end{array}$ & $\begin{array}{c}\text { No. of positive } \\
\text { samples }\end{array}$ & $\begin{array}{c}\text { \% of total } \\
\text { EHEC }\end{array}$ \\
\hline Minced Meat & 5 & 14.28 \\
Sausage & 4 & 11.4 \\
Luncheon & 2 & 5.7 \\
Total & 11 & 10.5
\end{tabular}

$\%$ were calculated according to the type of examined meat product sample 
After phenotyping and genotyping of isolates the prevalence of EHEC serogroupes was as following:

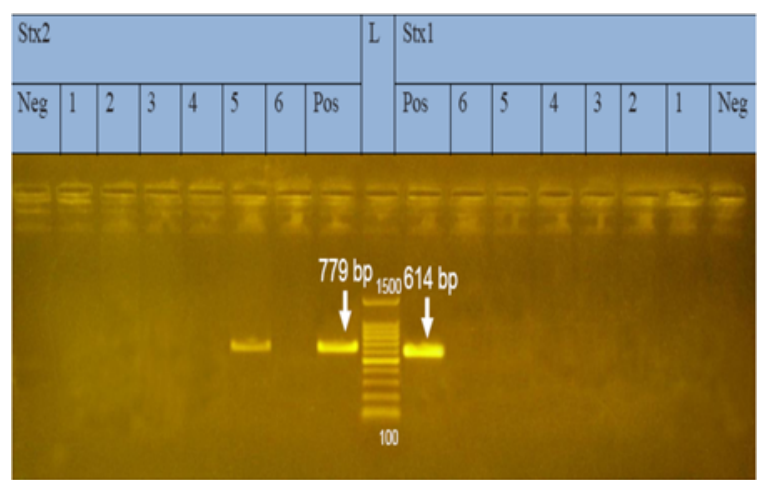

Fig. (1) PCR detection for virulence genes stx1 and stx2 of EHEC, the $s t x_{2}$ (779bp) gene. stx 2 : shiga toxin 2gene Lan L: 100-1500bp DNA Ladder Neg: Negative control. Pos: Positive control (at779bp) Lane 1, 2, 3, 4, 6: Enterohaemorrhagic E.coli (Negative). Lan 5: Enterohaemorrhagic E.coli 0157 (Positive). The stx1 (614 bp). Stx1: shiga toxin 1gene. Lane L: 1001500bpDNA Ladder. Neg.: Negative control. Pos.: positive control (at 614bp), Lane $1 ; 2 ; 3 ; 4,5$ \& 6: EHEC. (Negative).

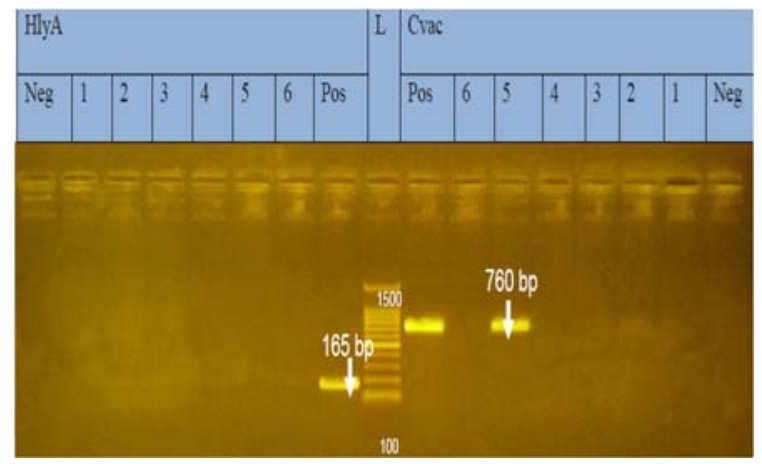

Fig. (2) PCR detection for virulence geneshlyA and cvaC genes of EHEC, hlyA (165 bp) gene. hlyA: Haemolysin gene. Lane L: 100-1500bp DNA Ladder. Neg.: Negative control. Pos.: positive control (at 165bp). Lane 1; 2; 3; 4, 5\&6: EHEC (Negative). The cvaC (760 bp) gene cvaC: colicine V production colV gene. Lan L:100-1500bp DNA Ladder Neg: Negative control. Pos: Positive control (at760bp) Lane 1, 2, 3, 4, 6: Enterohaemorrhagic E coli (Negative). Lane 5: Enterohaemorrhagic E.coli O15 (Positive)

The prevalence of E.coli $\mathrm{O}_{26}$ was $2 / 35$ (5.7\%), $2 / 35(5.7 \%), 1 / 35(2.85 \%)$ from minced meat, sausage and luncheon respectively with overall 5 samples $(4.7 \%)$ (Table 4$)$

The prevalence of E.coli $O_{111}$ was $1 / 35$ $(2.85 \%)$ from each type of meat products; with overall $3 / 105(2.85 \%)$ from all samples. The prevalence of EHEC $\mathrm{O}_{157}: \mathrm{H}_{7}$ was $3 / 105$ $(2.85 \%)$; represented as $2 / 35 \quad(5.7 \%)$, $1 / 35(2.85 \%)$ from minced meat and sausage, respectively. but in luncheon failed to recovered (Table 4)

Total EHEC were isolated from 11 samples with an incidence rate $(10.5 \%)$; represented as 5/35 (14.28\%); 4 /35(11.4\%); 2/35(5.7\%) from minced meat; sausage; Luncheon, respectively (Table5)

Table (6): The results of PCR amplification of different used genes of EHEC

\begin{tabular}{|c|c|c|c|c|c|}
\hline Sample & $\begin{array}{l}\text { I.D of } \\
\text { EHEC } \\
\text { strains }\end{array}$ & $\operatorname{stx}_{1}$ & $\mathrm{stx}_{2}$ & hlyA & CvaC \\
\hline $\begin{array}{l}\text { Luncheon } \\
\text { O26 }\end{array}$ & 1 & - & - & - & - \\
\hline $\begin{array}{l}\text { Minced meat } \\
\text { O26 }\end{array}$ & 2 & - & - & - & - \\
\hline $\begin{array}{l}\text { Sausage } \\
\text { O111 }\end{array}$ & 3 & - & - & - & - \\
\hline $\begin{array}{l}\text { Luncheon } \\
\text { O111 }\end{array}$ & 4 & - & - & - & - \\
\hline $\begin{array}{l}\text { Minced meat } \\
\text { O157 }\end{array}$ & 5 & - & + & - & + \\
\hline $\begin{array}{l}\text { Sausage } \\
\text { O157 }\end{array}$ & 6 & - & - & - & - \\
\hline
\end{tabular}

PCR results, table (6) showed that (stx2) and (cvaC) was detected in 1serogroup (O157)isolated from minced meat sample . The $s t x_{2}$ gene was giving product of (779 bp) and (cvaC) was giving product of (760bp) ,Moreover, the stx 1 and hIy A genes were not detected in all studied strain. Fig. (1 and 2).

\section{DISCUSSION}

EHEC was a subset of pathogenic E. coli causing diarrhea or hemorrhagic colitis in humans. Hemorrhagic colitis occasionally progresses to (HUS), an important cause of acute renal failure in children and morbidity and mortality in adults. In the elderly, the case fatality rate for hemolytic uremic syndrome (HUS) can be as high as $50 \%$. The infectious 
dose was very low, which increased the risk of disease (CFSPH, 2009).

There is no single technique that can be used to isolate all EHEC serogroups. So the samples were analyzed by duplicate. In the present study, (table 2) revealed that the incidence of E.coli (form minced meat, sausage and luncheon samples) were nearly agreed with Mousa et al., (1993), Fathi et al., (1994) and Sayed et al., (2001). Higher incidence was reported by Abou-Hussein (2004) and Reda et al., (2015). However, lower incidence rate was documented by Rabie (2014) with rates of $28 \%, 16 \%$ and $4 \%$ from minced meat, sausage and luncheon. The variation of the results between different authors may be due to the differences in manufacture practices, handling from producers to consumers, storage and the effectiveness of hygienic measures applied during production.

The species of E.coli are serologically divided into serogroups and serotypes on basis of their antigenic composition (somatic or $\mathrm{O}$ antigens for serogroups and flagella or $\mathrm{H}$ antigens for serotypes) (Griffin and Tauxe, 1991).

Therefore, the prevalence of EHEC $\mathrm{O}_{26}$ (table 4) were nearly similar to Ghoniem (1992) and O’Hanlon et al.,(2005) .Meanwhile, other results were different to us reported by Hazarika et al., (2004) and Stefen et al ., (2007) , Regarding, serogroup O111 (table 4) the obtained results nearly agreed with Ghoniem (1992) who detected E.coli $\mathrm{O}_{111}$ from 2\% luncheon but disagree with Ramadan (2015) who isolated E.coli $O_{111}$ from examined sausage and luncheon samples in higher prevalence rate $8 \%$ and $12 \%$, respectively.

The prevalence of $\mathrm{O}_{157}: \mathrm{H}_{7}$ in minced meat was nearly similar to Abdul-Raouf et al. (1996), Abd El-Aziz (2004) and Mewafy (2012). Moreover, the obtained result was higher than Fantelli and Stephan (2001) in
Switzerland and lower than Mora et al. (2007) and Hejazi (2013). Regarding sausage, the prevalence of EHEC $\mathrm{O}_{157}: \mathrm{H}_{7}$ in sausage (table 4) came parallel with Magwira (2005) and Hussein (2007). On the other hand, higher isolation rate of reported by AbuKhadra (2010) and Hejazi (2013).In some studies sausage have found to be free from EHEC $\mathrm{O}_{157}$ as Fayed (2006) and Mewafy (2012). Regarding luncheon E.coli $\mathrm{O}_{157}: \mathrm{H}_{7}$ failed to be detected in the all samples. These results go paraller with Sayedet al. (2001), Elsabagh (2010) and Mewafy (2012). This may be attributed to the competency of the organisms with other microorganisms in the food or heat treatment and preservation.

This percentage of isolation of EHEC indicated the role of this group of E.coli as potentially important food borne pathogen in Egypt. These findings were in line with Abdul-Roufet al., (1993) who indicated that the food of animal origin have been described as primary sources of EHEC infections.

On the other side, Saleh (2001) isolated EHEC in $16 \%$ of the examined meat product samples. There are many factors may affecting the differences in prevalence rates among studies such as type, source, initial bacterial load and the methodology used.

The PCR results showed that stx2 was detected in one serogroup $\mathrm{O}_{157}$ recovered from minced meat sample, while st $x_{1}$ was not detected in all samples .It has been reported that $\mathrm{O}_{157}: \mathrm{H}_{7}$ strains that express $s t x_{2}$ alone are more likely to be associated with progression to HUS than are strains producing stx 1 alone or, curiously, both stx 1 and stx $x_{2}$ (Pickering et al., 1994). These results go parallel with Blanco and Blanco (1996) who detected one EHEC $\mathrm{O}_{157}: \mathrm{H}_{7}$ strain produced only $V T_{2}$, Murphy et al., (2005) mentioned that non $\mathrm{O}_{26}$ isolates harbor stxs. Dambrosio et al., (2007) stated that none of all E.coli $\mathrm{O}_{26}$ isolates harbor $s t x_{1}$ or $s t x_{2}$ genes while Elsabagh 
(2010) found that E. coli $O_{111}$ is positive for $V T 1$ and $V T_{2}$, but $O_{26}$ is only positive for VT1, Gomez-Aldapa et al., (2013) reported that none of the $\mathrm{O}_{157}: \mathrm{H}_{7}$ strains had stx 1 or $s t x_{2}$. The PCR results (fig. 2) showed that cvaC virulence gene was detected in the same $\mathrm{O}_{157}: \mathrm{H}_{7}$ serogroup, whoever hly A genes were not detected in all studied samples. Moreover, These result disagree with Chinen (2001) recorded that all E.coli $\mathrm{O}_{157}$ isolates harbored EHEC-hlyA gene, Oteiza et al., (2006) stated that $\mathrm{O}_{26}$ strains harbored EHEC hly A gene and Dambrosio et al. (2007) who recorded that one $\mathrm{EHEC} \mathrm{O}_{26}$ isolate harbor hly A gene.

Conclusion: From the above mentioned results, this study recorded the high prevalence rate of EHEC especially non $\mathrm{O}_{157}: \mathrm{H}_{7}$. This indicated the role of this group of E.coli as potentially important food borne pathogen in Egypt. Moreover, the results cleared that not all EHEC harbored shiga toxins or other virulent genes.

\section{REFERENCES}

Abd El-Aziz, D.M. 2004. Microbiological and chemical hazards of some meat products. M.V.Sc. Thesis (Meat Hygiene). Fac. Vet. Med. Assiut Univ.

Abdul-Raouf, U.M., Ammar, M.S., Beuchat, L.R. 1996. Isolation of E.coli O157:H7 from some Egyptian foods. Int. J. Food Microbiol., 29:432-436.

Abdul-Raouf, U. M., Beuchat, L.R., Ammar, M. S.1993. Survival and growth of Escherichia coli O157: H7 in ground beef, roasted as affected by $\mathrm{pH}$, acidiulanls and temperature.Appl. Environ. Microbiol, 59 (8): 2384-2368.

Abou-Hussein, Reham, A.A. 2004. Microbiological evaluation of some meat products. M.V. Sc., Thesis, Fac. Vet. Med. Moshtohor, Benha Branch, Zagazig Univ.

Abu Khadra, A.M.A. 2010. Detection of Some Food Poisoning Microorganisms in Some Meat Products. M.V.Sc. Thesis (Meat Hygiene). Fac. Vet. Med. Alexandria Univ.
Adams, M. R., Moss, M. O. 2008. Food Microbiology. $3^{\text {rd }}$ Ed. Royal Society of Chemistry, Cambridge. 216-224.

APHA (American Public Health Association). 1992. Compendium of methods for the microbial examination of foods. $2^{\text {nd }} E d$. Academic Press. Washington, USA.

Blanco, J.E., Blanco, M. 1996. Detection of Enterohaeamorrhagic Escherichia coli O157:H7 in minced beef using immunomagnetic separation. Microbiol. 12(3):385-394.

CFSPH (Center for Food Security and Public Health) 2009. E.coli O157:H7 infections. Institute for international cooperation in animal biologies, Iowa State University.

Chelsa, R., O'Brien, A. 1998. Structure, biology and relative toxicity of Shiga toxin family members for cells and animals. In Kaper. J.B. O'Brien, A.D.(Eds.), Escherichia coli O157:H7 and other Shiga toxin-producing E.coli strains. American Society for Microbiology, pp. 121-128.

Chinen, I., Tanaro, J.D., Miliwebsky, E., Lound, L.H., Chillemi, G., Ledri, S., Baschkier, A., Scarpin, M., Manfredi, E., Rivas, M. 2001. Isolation and characterization of Escherichia coliO157:H7 from retail meats in Argentina. J. Food Prot. 64.

Dambrosio, A., Lorusso, V., Quaglia, N.C., Parisi, A., Salandra, La.G., Virgilio, S., Mula, G., et al. 2007. Escherichia coli O26 in minced beef: Prevalence, characterization and antimicrobial resistance pattern. Int. J. Food Microbiology (118):218-222.

Diez-Gonzalez, F. 2007. Applications of bacteriocins in Livestock. Current Issues of Intestinal Microbiology 8:15-24.

Dipineto, L., Santaniello, A., Fontanella, M., Lagos, K., Fioretti, A., Menna, L.F. 2006. Presence of Shiga toxin-producing Escherichia coli O157:H7 in living layer hens. Letters in Applied Microbiology 43: 293-295.

Elsabagh, R.A. 2010. Escherichia coli in meat and poultry products with special reference to identification of VTEC using the PCR technique. M.V.Sc. Thesis (Meat hygiene). Fac. Vet. Med. Banha Univ. 
Fantelli, K., Stephan, R. 2001. Prevalence and characteristics of shiga toxin-producing Escherichia coli and Listeria monocytogenes strains isolated from minced meat in Switzerland. Int. J. Food Microbiol., 70:63-69.

FAO/WHO (Food and Agriculture Organization of the United Nations/World Health Organization). 2011. Enterohaemorrhagic Escherichia coli in raw beef and beef products: approaches for the provision of scientific advice: meeting report. Microbiological Risk Assessment Series No. 18. Geneva, pp. 126.

Fathi, S., El-Khateib, T., Moustafa, S., Hassanein, K. 1994. Salmonellae and enteropathogenic E.coli in some locally manufactured meat products. Assuit Vet. Med. J. 31(61): 190199.

Fayed, A.M.S. 2006. E.coli in some meat products. M.V.Sc. Thesis, Fac. Vet. Med., Cairo University.

Ghoniem, A.A.M. 1992. Studies on pathogenic E.coli organisms in ready to eat meat products with special reference to diarrhea in children. M.V.Sc. (Food Hygiene), Fac. Vet. Med. Moshtor. Banha Branch. Zagazig. Univ.

Griffin, P. M., Tauxe, R. V. 1991. The epidemiology of infectious caused by Escherichia coli O157: H7, other enterohemorrhagic E.coli, and the associated hemolytic uremic syndrome. Epidemiol. Rev., 13:60.

Gómez-Aldapa, C.A., Díaz-Cruz, C.A., CernaCortes, J.F., Torres-Vitela Mdel, R.,Villarruel-López, A., Rangel-Vargas, E., Castro-Rosas, J. 2013. Escherichia coli $\mathrm{O} 157$ in ground beef from local retail markets in Pachuca, Mexico. J Food Prot.; 76(4):680-684.

Hazarika, R.A., Singh, D.K., Kapoor, K.N., Agarwal, R.K. 2004. Prevalence of different serotypes of E.coli in meat and its products. Indian J. Comp. Microbiol. Infec. Dis., 25(1):19-22.

Hejazi, H. A. M. 2013. Bacteria associated with some returned meat products. M.Sc. (Microbiology Dep.) Fac. vet. Med. Cairo Univ.
Hussein, H. S. 2007. Prevalence and pathogenicity of STEC in beef cattle and their products. J. Anim. Sci. 85: 63-72.

Kok, T., Worswich, D., Gowans, E. 1996. Some serological techniques for microbial and viral infections. In Practical Medical Microbiology (Collee, J.; Fraser, A.; Marmion, B. and Simmons, A., eds.), 14th ed., Edinburgh, Churchill Livingstone, UK.

Magwira, C. A., Gashe, B. A., Collison, E. K. 2005. Prevalence and antibiotic resistance profiles of E.coli O157:H7 in beef products from retail outlets in Gaborone, Botswana. J. Food Prot., 68(2):403-406.

Malik, K., Memona, H. 2010. Molecular and immunological studies of pathogenic Escherichia coli in meat samples collected from different localities of Lahore. International Journal of Cell \& Molecular Biology (IJCMB) 1(3):218-224.

Mewafy, Abeer.A.A. 2012. Characterization of E.coli $\mathrm{O} 157: \mathrm{H} 7$ isolated from meat and meat products. Ph.D. Thesis (microbiology Dep.)Fac. Vet. Med. Cairo Univ.

Mora, A., León, S.L., Blanco, M., Blanco, J.E., López, C., Dahbi ,G.,Echeita, A., González, E.A., Blanco, J. 2007. Phage types, virulence genes and PFGE profiles of STEC O157:H7 isolated from raw beef meat, soft cheese and vegetables in Lima (Peru). Int J Food Microbiol 2007, 114:204210.

Mousa, M., Awad H., Yassien M., Gouda H. 1993. Microbial quality of some meat products. Alex. Vet. Med. J., 41:59-62.

Murphy, M., Carroll, A., Whyte, P., O’Mahony, M., Anderson, W., McNamara, E. and Fanning, S. 2005. Prevalence and characterization of Escherichia coli O26 and $\mathrm{O} 111$ in retail minced beef in Ireland. Food borne Pathog Dis 2(4):357-360.

Nataro, J.P., Kaper, J.B. 1998. DiarrheagenicEscherichia coli.Clinical Micro. Reviews: 11 (1):142-201.

O'Hanlon, K.A., Catarame, T.M.C., Blair, McDowell, D.A., Duffy, G. 2005. Culture method to detect E.coli O26 and O111 in minced beef in Republic of Ireland food Microbiology, 22(6):553-560.

Oteiza, J.M., Chinen, L., Miliwebsky, E., Rivas, M. 2006. Isolation and characterization of 
shiga toxin-producing Esherichia coli from precooked sausage. Food Microbiology 23: 283-288.

Parry, Sharon 2002. Escherichia coli: Environmental Health issues of VTECO157. London; New York: Span Press.

Pickering, L.K, Obrig, T.G, Stapleton, F. B. 1994.Hemolytic-uremic syndrome and enterohemorrhagic Escherichia coli. Pediatr Infect Dis J.; 13:459-476

Quinn, P.J., Markkey, B.K., Carter, M.E., Donnelly, W.J.C., Leonard, F.C. 2002. Veterinary Microbiology and Microbial Disease. Black Well Scientific Publication, Oxford, London

Rabie, MarwaAbd El-Hak Mahmoud. 2014. Molecular characterization of pathogenic E. coli isolated from meat and their products. Department Bacteriology, Immunology and Mycology, Fac. Vet. Med. Suez Canal Univ

Ramadan, A.M. 2015. Contamination of meat products with human pathogens. Faculty of vet. medicine, Alexandria Univ., Meat Hygiene Dep.

Reda, Tarabees., Zakaria, H. Hassanin., EL Bagoury, A.M. 2015. Polymerase Chain Reaction (PCR): An Alternative Rapid Method for Detection of Some Microbial Contamination of Meat Products. Alexandria Journal of Veterinary Sciences.
Periodical of Fac. Vet. Medicine Alexandria Univ.

Saleh, S.K. 2001. Prevalence of enterohaemorrhagic E.coli in some meat products. J. Egypt. Vet. Med. Assuit. 61 (4):173-178

Sambrook, J., Fritsh, E. F., Maniatis, T. 1989. Molecular Cloning: A Laboratory Manual, $2^{\text {nd }}$ Ed Cold Spring Harbor Laboratory press, Cold Spring Harbor, NY.

Sayed, A. M., Abou EI-Alla, A. A., Abd EIHafeez, M. M., Hussein, A. A. A., Hassanien, Z. A. 2001. Prevalence of Escherichia coli with special reference to E.coli $\mathrm{O} 157$ in some retail meat products and cattle in Assiut Governorate. Assiut Vet. Med. J. 45(90): 146-156.

Stefen, A., Scaramagli, S., Bergani, R., Mazini,C., Barbanera, M., Perelle, S., Fach, P. 2007. Real-time PCR and enzyme linked fluorescent assay methods for detection Shiga toxin producing E.coli in minced meat samples. Canadian J. Microbiol., 53(3):337-342.

Yaguchi, K., Ogitani, T., Osawa, R., Kawano, M., Kokumai, N., Kaneshige, T., Noro,T., Masubuchi, K., Shimizu, Y. 2007. Virulence Factors of Avian Pathogenic Escherichia coli Strains isolated from Chickens with Colisepticemia in Japan. 51(3):656-662 